\title{
Pemberdayaan Masyarakat Melalui Pelatihan Pembuatan Pakan Alternatif Amoniasi Jerami Jagung di Nagari Pelangai Kaciak Kecamatan Ranah Pesisir, Pesisir Selatan
}

Tinda Afriani dan Yoga Seftiadi

Fakultas Peternakan, Universitas Andalas, Kampus Limau Manis, Padang, 25163. Indonesia

E-mail: tindaafriani@ansci.unand.ac.id

Keywords: ammoniation, corn straw, Pesisir Selatan, ruminant's feeding,

\begin{abstract}
Roughage has been needed for main source of ruminant's feeding. However the main obstacle faced by farmers during the dry season is an availability of fresh forage feed, which is only corn straw. They have lack skill of fermentation technique of roughage to increase its quality and period of storage. The purpose of this activity was to provide knowledge and skills for farmers in terms of management and utilization of agricultural waste such as corn straw. This activity was carried out both counseling and training method of ammoniation of corn straw by farmer in Nagari Pelangai Kaciak, Ranah Pesisir District, Pesisir Selatan - West Sumatra. The result of this activity was transformation process of certain knowledge from academia to farmer, so as they understood a reason for doing ammoniation step. It was expected that having multiply impacts for surrounding, for instance not only rising quality of corn straw, but also improving livestock's management and providing friendly environment.
\end{abstract}

\begin{abstract}
ABSTRAK
Pakan merupakan suatu kebutuhan mutlak yang harus dipenuhi dalam pemeliharaan ternak ruminansia baik itu kambing, domba, sapi maupun kerbau. Namun kendala utama yang dihadapi peternak saat musim kemarau yaitu ketersediaan pakan hijauan segar yang sulit didapatkan, yang ada hanya jerami jagung. Tujuan kegiatan ini dilakukan yaitu memberikan pengetahuan dan keterampilan kepada peternak dalam hal pengelolaan dan pemanfaatan limbah pertanian seperti jerami jagung. Kegiatan ini dilakukan dengan metode penyuluhan dan pelatihan, metode penyuluhan dilakukan dengan memberikan ceramah tentang manfaat amoniasi jerami jagung, sedangkan pelatihan dilakukan dengan mempraktekan carapembuatan amoniasi jerami jagung. Kegiatan ini dilakukan oleh mahasiswa KKN Unand dari fakultas peternakan. Kegiatan ini dihadiri oleh kelompok ternak, masyarakat umum serta aparat Nagari Pelangai Kaciak. Hasil dari kegiatan ini adalah peternak telah mengetahui cara pembuatan dan manfaat amoniasi jerami jagung. Diharapkan dari kegiatan ini dapat memberikan informasi cara pengolahan jerami jagung sebagai pakan alternatif untuk ternak ruminansia dengan metoda amoniasi, mengatasi kesulitan pakan pada musim kemarau serta dapat membantu sanitasi lingkungan.
\end{abstract}




\section{PENDAHULUAN}

Nagari Pelangai Kaciak merupakan salah satu nagari yang terdapat di Kecamatan Ranah Pesisir, Kabupaten Pesisir Selatan yang umumnya masyarakatnya sebagai petani. Selain sebagai petani, masyarakat disini juga memiliki usaha ternak Pada tahun 2017 populasi ternak besar di Nagari Pelangai Kaciak seperti sapi potong dengan jumlah 533 ekor yang terdiri dari 61 ekor jantan dan 472 ekor betina, kerbau dengan jumlah 13 ekor yang terdiri dari 3 ekor jantan dan 10 ekor betina. Usaha ternak yang dilakukan oleh masyarakat disini hanya usaha sampingan bukan dijadikan prioritas utama sebagai ternak potong. Bahkan setiap peternak yang memelihara sapi jumlahnya terbilang sedikit. Semi intensif merupakan sistem pemeliharaan yang dilakukan oleh peternak yaitu sapi-sapi dikandangkan pada malam hari, namun pada pagi sampai sore hari sapi dilepaskan atau digembalakan di daerah perbukitan maupun persawahan.

Jenis sapi yang banyak dipelihara di Nagari Pelangai Kaciak yaitu jenis sapi Pesisir dan sapi Bali, namun lebih dominan sapi Pesisir. Alasan peternak memelihara sapi hanya sebagai usaha sampingan yaitu untuk memenuhi kebutuhan ketika waktu mendesak seperti biaya anak sekolah, saat sakit maupun biaya mendesak lainnya sehingga saat seperti itu dimanfaatkan sapi yang dipelihara dijual. Kelemahan dari metode pemeliharaan seperti ini yaitu pakan sapi tidak terlalu diperhatikan sebab perhatian masyarakat lebih fokus pada usaha utamanya yaitu bertani. Sowmen dkk (2018) menyatakan permasalahan yang sering dihadapi oleh peternak sapi yaitu manajemen pemeliharaan kurang baik, ketersedian pakan yang kurang memadai, rendahnya nilai gizi pakan yang diberikan, pengetahuan birahi yang masih kurang serta penanganan penyakit. Pemeliharaan sapi tidak hanya bagaimana sapi-sapi yang dipelihara bisa makan dan tumbuh besar begitu saja. Peternak harus memperhatikan aspek-aspek terkait dalam hal pemeliharaan sapi. Aspek-aspek tersebut meliputi pakan yang diberikan, perkandangan, penanganan kesehatan, perkawinan, pengelolaan limbah, serta aspek terkait lainnya diharapkan akan menghasilkan produktivitas yang tinggi. Kendala yang terdapat di dalam pemeliharaan sapi potong diantaranya adalah kurangnya pengetahuan masyarakat terhadap Good Farming Practices dan penerapannya yang menyebabkan pemeliharaan sapi-sapi tersebut kurang maksimal.

Nagari Pelangai Kaciak memilki potensi besar untuk dikembangkan sebagai daerah penghasil ternak potong karena di daerah ini banyak ditemukan hijauan dan limbah pertanian yang cukup melimpah. Salah satunya jerami jagung, setelah panen jerami jagung kebanyakan dibakar dan kurang dimanfaatkan disebabkan kurangnya pengetahuan dari masyarakat atau peternak dalam pengolahannya sebagai pakan ternak. Menurut Bahar (2016) bahwa potensi limbah tanaman jagung pada saat ini masih belum dimanfaatkan sepenuhnya sebagai pakan ternak. Bila dilihat dari potensinya maka dapat dimanfaatkan secara maksimal sebagai pakan ternak yang akan meningkatkan kapasitas tampung ternak. Semakin berkembangnya usaha pertanian khususnya tanaman jagung sekaligus merupakan peluang yang dapat dimanfaatkan sebagai salah satu strategi dalam pengembangan usaha ternak ruminansia mengingat limbah atau hasil samping berupa jerami yang cukup potensial dijadikan sebagai sumber pakan ternak. Pendapatan usahatani sistem integrasi tanaman jagung dan sapi dapat memperoleh nilai ganda, sehingga sistem integrasi tanaman jagung dan sapi potong merupakan usahatani aneka panen.

Salah satu cara pengolahan yang sangat efisien dan mudah dilakukan adalah amoniasi, yaitu dengan menambahkan urea dan air pada bahan yang diamoniasi. Menurut Klopfenstein (1987) amoniasi merupakan salah satu perlakuan kimia yang bersifat alkalis yang dapat melarutkan hemiselulosa dan akan memutuskan ikatan lignin dengan selulosa dan hemiselulosa. Sesuai dengan pendapat Van Soest (1982) amoniasi dapat melarutkan sebagian silika karena silika mudah larut dalam alkali dan menurunkan kristanilitas selulosa.

Berdasarkan uraian diatas dapat dirumuskan beberapa permasalahan yang dihadapi peternak di Nagari Pelangai Kaciak yaitu kurangnya pengetahuan masyarakat dalam pemanfaatan limbah pertanian untuk diolah menjadi pakan ternak serta sistem pemeliharaan sapi yang belum tepat. Diharapkan setelah dilakukan penyuluhan dan pelatihan masyarakat lebih semangat dalam melakukan usaha ternak potong dan pemanfaatan limbah pertanian untuk 
diolah menjadi pakan alternatif dengan metode amoniasi. Sehingga mampu meningkatkan kesejahteraan masyarakat di Nagari Pelangai Kaciak, Kecamatan Ranah Pesisir, Kabupaten Pesisir Selatan.

\section{METODE}

Kegiatan ini dilaksanakan pada tahun 2019 di Nagari Pelangai Kaciak, dengan melibatkan mahasiswa KKN Unand dari Fakultas Peternakan yang terdiri dari beberapa tahapan yaitu persiapan, penyuluhan dan pelatihan.

\section{Persiapan}

Tahapan persiapan dimulai dengan mencari permasalahan yang terdapat di Nagari, melakukan survei lokasi untuk diadakan penyuluhan dan pelatihan. Selanjutnya mempersiapkan materi yang akan disampaikan, bahan serta peralatan yang digunakan saat melakukan penyuluhan dan pelatihan (Ediset dkk, 2018).

\section{Penyuluhan}

Tahapan kegiatan pertama yaitu melakukan penyuluhan dengan metode sosialisasi (Anwar dkk, 2009). Metode sosialisasi dilakukan saat pengenalan pemanfaatan limbah pertanian seperti jerami jagung dan manfaat dilakukannya pengolahan jerami jagung dengan metode amoniasi. Sosialisasi dilakukan dengan menjelaskan langkah-langkah pembuatan amoniasi jerami jagung yang meliputi bahan dan alat yang akan digunakan serta manfaat dari produk amoniasi.

\section{Pelatihan}

Pelatihan dilakukan setelah kegiatan penyuluhan dilaksanakan yaitu setelah materi disampaikan langsung dilakukan pelatihan pembuatan pakan alternatif jerami jagung dengan metode amoniasi. Antusiasme masyarakat dilihat dari setiap pertanyaan yang diajukan selama melakukan pelatihan dan penyuluhan. Kegiatan pelatihan dilakukan diruangan terbuka dengan melibatkan masyarakat secara langsung agar lebih mudah dipahami. Metoda amoniasi yang dilakukan merujuk kepada metoda yang dilakukan oleh Bahar (2016). Amoniasi jerami jagung dibuat dari bahan-bahan yang terdiri dari jerami jagung yang telah dicacah atau dipotong dengan ukuran 3-5 $\mathrm{cm}$ sebanyak $5 \mathrm{~kg}$, urea sebanyak 6\% dari bobot jerami dan air, sedangkan alat-alat yang digunakan yaitu ember, timbangan, plastik, tali raffia, terpal. Jerami yang telah dicacah dihamparkan diatas terpal plastik kemudian dipercikkan larutan urea secara merata hingga semua jerami lembab. Masukkan jerami ke dalam plastik dan diikat dengan tali dengan kuat hingga proses amoniasi berlangsung selama 3 minggu.

\section{HASIL DAN PEMBAHASAN}

Berdasarkan hasil kegiatan yang telah dilakukan antusiasme masyarakat sangat besar terhadap kegiatan yang dilakukan. Hal ini tampak pada peserta yang hadir dalam penyuluhan dan pelatihan yang dilakukan. Adapun yang hadir yaitu peternak, petani dan dari kalangan anakanak yang memiliki semangat yang tinggi untuk menghadiri acara penyuluhan dan pelatihan yang dilakukan. Antusiasme masyarakat sangat tinggi karena banyaknya pertanyaan yang diajukan baik itu tentang manfaat amoniasi maupun cara pengolahannya sehingga terciptanya suasana diskusi yang baik.

\section{Persiapan Kegiatan}

Kegiatan persiapan dilakukan dengan melihat lokasi dan potensi yang ada di Nagari Pelangai Kaciak. Kegiatan ini dilakukan dengan mempersiapkan semua bahan dan peralatan yang akan digunakan saat pelatihan. 


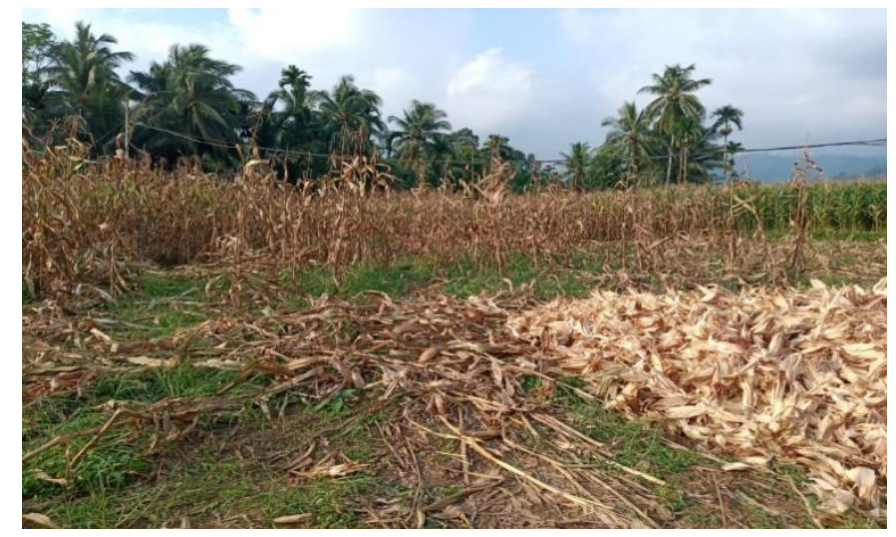

Gambar 1. Jerami Jagung di Lahan Pertanian

Berdasarkan gambar diatas tampak jelas bahwa setelah selesai panen, jerami jagung yang terdiri dari batang, kelobok atau kulit jagung dibuang atau dibiarkan.Padahal jerami tersebut bisa dimanfaatkan sebagai pakan ternak melalui pengolahan terlebih dahulu. Menurut Sariubang, dkk (2007) bahwa potensi jerami jagung per hektar rata-rata 10,8 ton kering panen. Persiapan selanjutnya yaitu melakukan pemotongan atau pencacahan jerami jagung seperti pada Gambar 2.
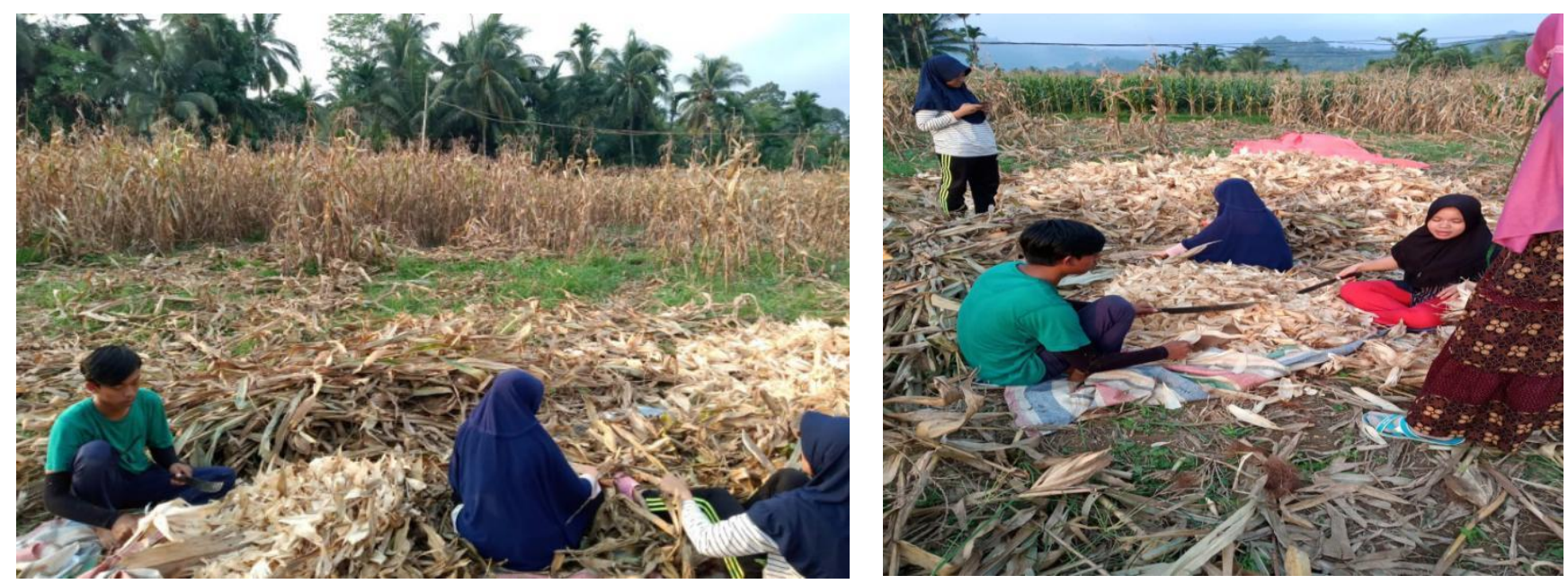

Gambar 2. Proses Pencacahan Jerami Jagung

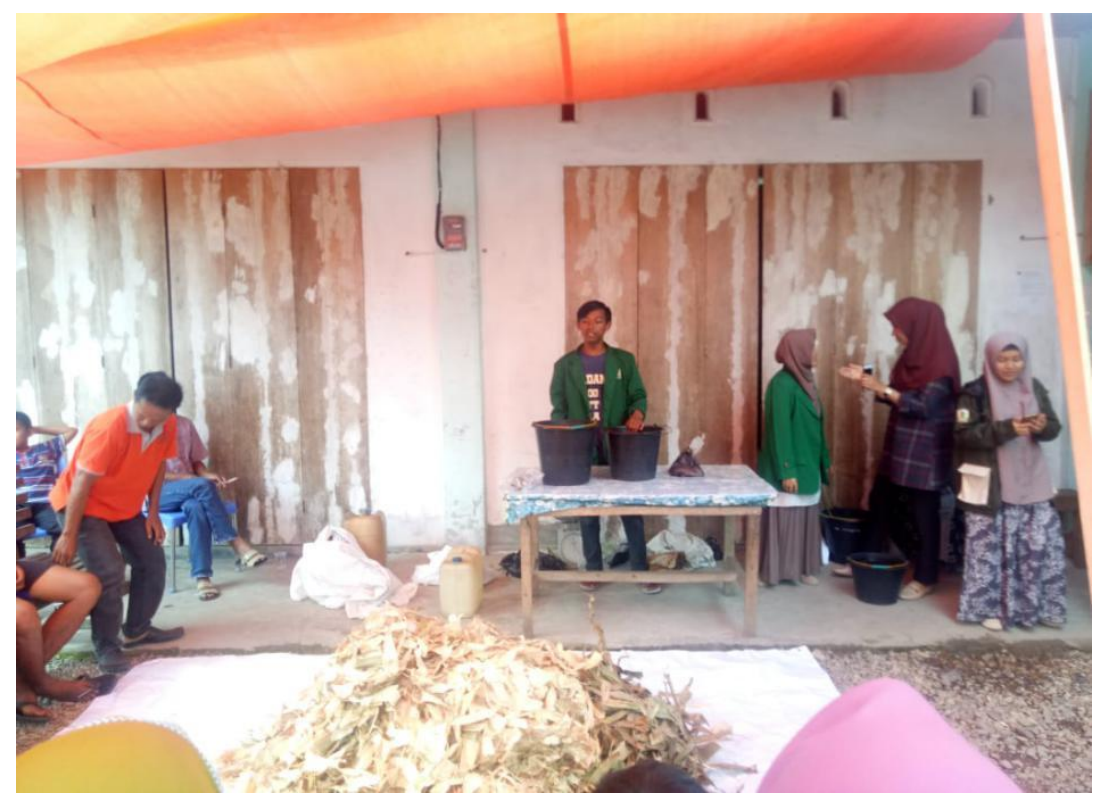

Gambar 3. Penyuluhan Pembuatan Pakan Amoniasi Jerami Jagung 


\section{Penyuluhan Pembuatan Pakan Alternatif Amoniasi Jerami Jagung}

Kegiatan penyuluhan ini dilakukan dengan metode sosialisasi, dimana disampaikan atau dikenalkan amoniasi jerami jagung. Selanjutnya disampaikan beberapa manfaat dilakukannya pengolahan amoniasi jerami jagung sebagai pakan ternak. Kegiatan ini dihadiri oleh masyarakat umum, peternak, petani dan perangkat nagari. Tempat pelaksanaan kegiatan dilakukan dilapangan terbuka sehingga bisa langsung dilakukan pelatihan pembuatan pakan alternatif dari amoniasi jerami jagung.

Berdasarkan gambar diatas tampak bahwa sebelum dilakukan pelatihan diberikan terlebih dahulu materi tentang teknik amoniasi jerami jagung. Jerami jagung mempunyai potensi besar sebagai sumber pakan, namun kualitasnya cukup rendah. Beberapa kandungan nutrisi yang terdapat dalam jerami jagung diantaranya protein5,56\%, serat kasar 33,58\%, lemak kasar 1,25, abu 7,28 dan BETN 52,32\% (BPTP Sumatera Barat, 2011). Data tersebut menjelaskan bahwa kendala utamanya adalah nilai nutrisi dari penggunaan limbah tanaman pertanian, seperti jagung yang masih rendah, hal ini karena tingginya kandungan serat kasar. Oleh karena itu diperlukan perlakuan agar kualitasnya dapat ditingkatkan antara lain dengan cara amoniasi.

Amoniasi adalah cara perbaikan mutu pakan melalui pemberian urea sebagai Non protein nitrogen (NPN) yaitu pemberian urea yang hanya dimanfaatkan pada ternak ruminansia terutama ternak besar seperti sapi dan kambing, sedangkan ternak monogastrik seperti kuda tidak cocok diberikan sebagai pakan. Tujuannya adalah dapat meningkatkan kandungan protein dalam ransum, sehingga mutu pakan juga akan meningkat. Perlu diperhatikan bahwa urea yang digunakan hanya dalam jumlah sedikit, karena kalau berlebihan akan berakibat fatal bagi ternak. Selama kegiatan penyuluhan dilakukan tercipta suasana diskusi hal itu terlihat banyak pertanyaan yang diajukan oleh masyarakat.

\section{Pelatihan Pembuatan Pakan Alternatif Amoniasi Jerami Jagung}

Tujuan dilakukan pelatihan secara langsung agar masyarakat atau peternak bisa mempraktekan langsung nantinya setelah pelatihan selesai.
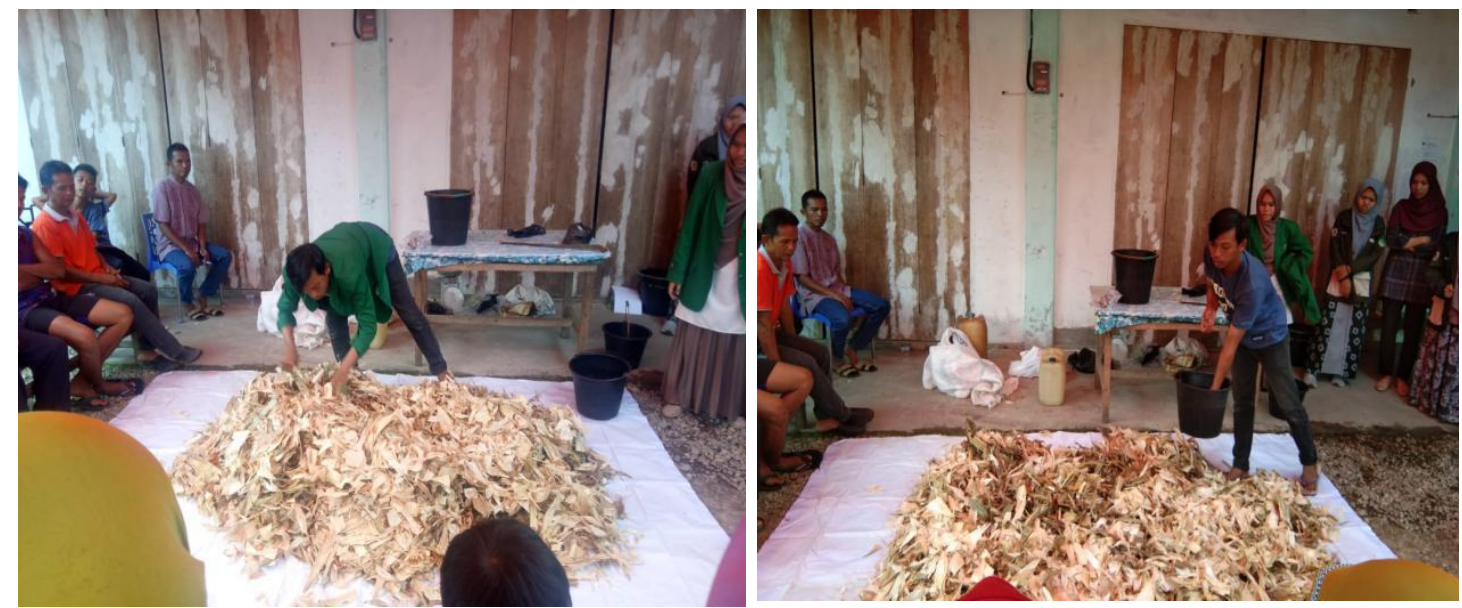

Gambar 4. Pembuatan Pakan Alternatif Amoniasi Jerami Jagung

Kegiatan ini dilakukan pada sore hari dengan jumlah peserta sekitar 20 orang yang terdiri dari peternak, petani, perangkat nagariserta mahasiswa KKN Unand yang sedang melaksanakan KKN di Nagari Pelangai Kaciak. Menurut Bahar (2016) bahwa dari segi kualitas jerami jagung berdasarkan hasil analisa proksimat diketahui memiliki rata-rata kualitas untuk Protein kasar 6,38 \%, Serat kasar 30,19 \%, Lemak kasar 2,81 \%, BETN 51,69 \%, Abu 8,94 \% dan kandungan TDN (Total Digestible Nutrient) 53,12 \%. Berdasarkan data ini , bahwa kandungan nutrisi jerami tidak sama, hal ini disebabkan karena tempat lokasi percobaan dengan kesuburan tanahnya, irigasi, umur tanam, pemupukannya berbeda (Hidayat, 2015).

Berdasarkan hasil penelitian Susilawati dkk, (2013) bahwa jika dilihat dari hasil analisis kandungan bahan kering maupun bahan organik cenderung turun namun apabila ditinjau dari 
kandungan protein kasar terlihat bahwa jerami tanpa perlakuan adalah terendah dibandingkan dengan jerami yang mengalami perlakuan. Pada jerami amoniasi terlihat bahwa kandungan protein kasar cenderung naik hal ini disebabkan karena proses amoniasi ditambah urea yang mengandung nitrogen kurang lebih $46 \%$, sehingga kandungan protein cenderung naik karena nitrogen merupakan unsur pembentuk protein. Selanjutnya Susilawati dkk, (2013) menyatakan apabila ditinjau dari aroma pada jerami amoniasisetelah dibuka dari kantong plastik terasa bau menyengat karena adanya amonia, sehingga apabila jerami amoniasi tersebut akan diberikan pada ternak sapi harus diangin-anginkan terlebih dahulu agar ternak mau memakannya.

Menurut Howlett et al.(2003) pemberian silase tanaman jagung kepada sapi potong menghasilkan performans reproduksi yang tidak berbeda nyata bila disuplemen dengan konsentrat campuran jagung dan bungkil kedelai. Hal ini mengindikasikan bahwa pengolahan jerami jagung mampu meningkatkan palatabilitas pakan sehingga meningkatkan kecernaan yang akan berdampak kepada performan reproduksi ternak.

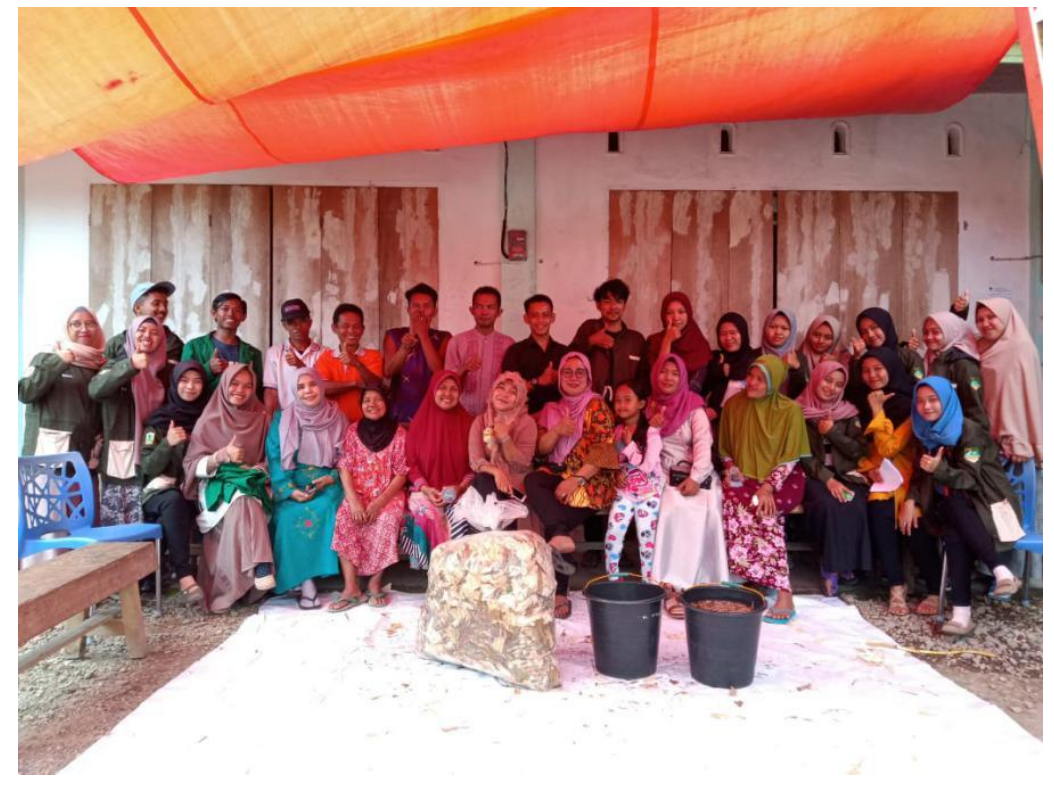

Gambar 5. Hasil Pembuatan Pakan Alternatif

Bentuk upaya dalam peningkatan nilai gizi limbah pertanian dengan menggunakan teknologi amoniasi ini belum sepenuhnya diterapkan di masyarakat. Jika dilihat dari kalangan peternak penerapan teknologi amoniasi ini memiliki beberapa kendala, seperti kurang tersedianya fasilitas untuk penyimpanan pakan, munculnya penambahan beban biaya yang cukup banyak serta kurangnya keinginan masyarakat untuk menggunakan teknologi ini, akibat dariminimnya pengetahuan masyarakat (Bahar, 2016). Diharapkan setelah kegiatan ini selesai mampu meningkatkan motivasi masyarakat di Nagari Pelangai Kaciak untuk memanfaatkan potensi yang ada sehingga mampu meningkatkan kesejahteraan masyarakat.

\section{KESIMPULAN}

Kegiatan ini memberikan pengaruh yang positif bagi peternak karena dapat meningkatkan pengetahuan dan keterampilan peternak dalam memanfaatkan limbah pertanian salah satunya jerami jagung. Selain itu mampu mengatasi sanitasi lingkungan tanpa harus membakar limbah pertanian. Kontribusi petugas dan penyuluh lapangan sangat diharapkan agar dapat mengatasi permasalahan peternak. Untuk kegiatan yang berkelanjutan diharapkan sesama peternak mampu membagi pengetahuan yang telah didapatkan serta peran petugas dan penyuluh lapangan yang sangat diharapkan peternak. 


\section{UCAPAN TERIMA KASIH}

Tim pelaksana kegiatan mengucapkan terimakasih kepada Universitas Andalas Padang melalui LP2M dan PU KKN yang telah mempercayakan pada kami untuk melaksanakan kegiatan ini, serta menfasilitasi artikel kegiatan sampai dipublikasi.

\section{DAFTAR PUSTAKA}

Anwar, S. Madariza, F dan Anas, A. 2009. Ilmu Penyuluhan Pertanian. Padang: Universitas Andalas.

Bahar, S. 2016. 'Teknologi pengelolaan jerami jagung untuk pakan ternak ruminansia', Buletin Pertanian Perkotaan, 6(2), hal.23-29.

BPTP Sumatera Barat. 2011. Teknologi Pembuatan Silase Jagung untuk Pakan Sapi Potong. Badan Litbang Pertanian Kementerian Pertanian Republik Indonesia. Sumber:http//sumbar.litbang.pertanian.go.id. Diakses 15 Maret 2018.

Ediset, E. Harianto dan A. Anas. 2018. 'Perbaikan usaha peternakan sapi pada aspek pakan di Nagari Siguntur, Kecamatan Sitiung, Dharmasraya', Buletin Ilmiah Nagari Membangun, 1(4), hal.139-145.

Hidayat, H. 2015. Komposisi nutrisi jerami jagung di Kecamatan Gerung Kabupaten Lombok Barat untuk pakan sapi. Skripsi Program Studi Peternakan Fakultas Peternakan Universitas Mataram.

Howlett, C. M., E. S. Vanzant, L. H. Anderson, W. R. Burris, B. G. Fieser and R. F. Bapst. 2003. 'Effect of supplemental nutrient source on heifer growth and reproductive performance, and on utilization of corn silage-based diets by beef steers', J. Anim. Sci., 81, p.2367-2378.

Klopfenstein, T. 1987. 'Chemical treatment of crop residues', J. Anim. Sci., 6, p.841-848.

Sariubang, M., S. N. Tambing dan Sahardi. 2007. Pengkajian sistem integrasi tanaman jagung sapi potong di lahan kering, Sulawesi Selatan. Prosiding Seminar Nasional Balai Pengkajian Teknologi Pertanian Sulawesi Selatan, Makassar 2-3 Agustus 2007.

Sowmen, S. Khasrad dan Rusdimansyah. 2018. 'Introduksi ipteks pada peternakan sapi di kelompok tani Rawang Saiyo dan kelompok tani Tuah Sepakat', Jurnal Hilirisasi IPTEKS, 1(3), hal.46-53.

Susilawati, T. dan Sudarwati, H. 2013. 'Pemanfaatan sumber daya pakan lokal melalui integrasi ternak sapi potong dengan usaha tani', J. Ternak Tropika, 14(2), hal.23-30.

Van Soest, P. J. 1982. Nutritional ecology of ruminant: Ruminant metabolism, nutritional strategies, the cellulolytic fermentation and the chemistry of forages and plant fibers. Ithaca: Cornell University Press. 